\title{
Strategies to boost economic and tourist development, under the scheme of Magical Towns in Xicotepec de Juárez, Puebla
}

\section{Estrategias para impulsar el Desarrollo Económico y Turístico bajo el esquema de Pueblos Mágicos en Xicotepec de Juárez, Puebla}

\author{
VELÁZQUEZ-VARGAS, José Rubén†*, CRUZ-CABRERA, Clotilde, CARMONA-GONZÁLEZ, \\ Juan Carlos and VAZQUEZ-ARROYO, Felipe
}

Universidad Tecnológica de Xicotepec de Juárez. División Económico Administrativa. Av. Universidad Tecnológica Núm.1000 Col. Tierra Negra, C.P.: 73080, Xicotepec de Juárez, Puebla

ID $1^{\text {st }}$ Author: José Rubén, Velázquez-Vargas / ORC ID: 0000-0002-3085-5515, Researcher ID Thomson: X-2948-2018, CVU CONACYT ID: 953306

ID $1^{\text {st }}$ Coauthor: Clotilde, Cruz Cabrera / ORC ID: 0000-0002-4516-7061, Researcher ID Thomson: S-6899-2018, CVU CONACYT ID: 953328

ID $2^{\text {nd }}$ Coauthor: Juan Carlos, Carmona-González / ORC ID: 0000-0002-2489-7882, Researcher ID Thomson: Y-18042018, CVU CONACYT ID: 954425

ID $3^{\text {rd }}$ Coauthor: Felipe, Vazquez-Arroyo / ORC ID: 0000-0002-2142-5978, CVU CONACYT ID: 1006104

DOI: $10.35429 /$ EJRC.2019.9.5.17.23

Received July 27, 2019; Accepted December 20, 2019

\begin{abstract}
Resumen
Las condiciones cambiantes de la economía en nuestro País, aunadas a un riguroso entorno global; demandan alternativas que permitan lograr una administración eficiente de la producción de bienes y servicios para alcanzar las condiciones favorables que generen los medios materiales de bienestar para conservar el mismo nivel de vida en cualquiera de las entidades que lo conforman. Resulta prioritario conocer actualmente en el Municipio de Xicotepec de Juárez, Pue. su valor cultural para generar estrategias que fortalezcan su economía y contribuyan a la preservación de las raíces culturales y afianzar la sustentabilidad turística. Para tal efecto, se realizó un estudio empírico cuantitativo mediante un instrumento de investigación de campo para identificar las acciones de sustentabilidad emprendidas, análisis de mercado gestión de ventas, producción, operación, capacidad instalada, finanzas y uso de la tecnología en las Micro y pequeñas empresas (MYPES) de la localidad. Obteniendo diversos resultados que hacen notoria la carencia de una cultura empresarial que permita el adecuado desarrollo de la economía local. Por lo que se aspira contribuir con el diseño de estrategias que permitan lograr una sustentabilidad turistica y mejorar las condiciones económicas sociales y ambientales además de preservar tradiciones y raices culturales en Xicotepec de Juárez, Pue.
\end{abstract}

\begin{abstract}
The changing conditions of the economy in our country, coupled with a rigorous global environment; they demand alternatives that allow to achieve an efficient administration of the production of goods and services to reach the favorable conditions that generate the material means of well-being to preserve the same standard of living in any of the entities that comprise it. It is a priority to know currently in the Municipality of Xicotepec de Juárez, Pue. its cultural value to generate strategies that strengthen its economy and contribute to the preservation of cultural roots and strengthen tourism sustainability. For this purpose, a quantitative empirical study was carried out through a field research instrument to identify the sustainability actions undertaken, market analysis, sales management, production, operation, installed capacity, finance and use of technology in Micro and small local businesses (MYPES). Obtaining various results that makes evident the lack of a business culture that allows the proper development of the local economy. Therefore, we hope to contribute to the design of strategies that allow achieving tourist sustainability and improving social and environmental economic conditions as well as preserving traditions and cultural roots in Xicotepec de Juárez, Pue.
\end{abstract}

Sustainability, Development, Strategies

Citation: VELÁZQUEZ-VARGAS, José Rubén, CRUZ-CABRERA, Clotilde, CARMONA-GONZÁLEZ, Juan Carlos and VAZQUEZ-ARROYO, Felipe. Strategies to boost economic and tourist development, under the scheme of Magical Towns in Xicotepec de Juárez, Puebla. ECORFAN Journal-Republic of Cameroon. 2019, 5-9: 17-23

\footnotetext{
* Correspondence to Author (email: ruben.velazquez@utxicotepec.edu.mx)

$\dagger$ Researcher contributing first Author.
} 


\section{Introduction}

In the current globalizing global context, it is a priority to preserve the territorial identity roots that each region possesses since local economies are distinguished by certain natural and cultural heritage. Nature and culture have a high symbolic value, to the extent that the same community recognizes it as a value (Nieto Mejía, A., 2013).

Disseminating the values that various localities possess is achieved through activities that promote cultural, emotional and recreational experiences, which are carried out through tourism since the geographical space that contains various worldviews can be disseminated as a cultural identity. The territory as a cultural framework is not only a generator of values, but of memory and identification (Galimberti, C., 2013)

Identify those particularities that distinguish Xicotepec de Juárez, make a difference in what is produced and offered to visitors. The article aims to identify cultural wealth to develop proposals that strengthen the economy and contribute to the preservation of cultural roots and the strengthening of tourism sustainability and thus contribute to the design of strategies and incentives that allow improving social and environmental economic conditions.

\section{Tourism in the Region}

One of the main economic activities that generate foreign exchange is tourism; According to the World Tourism Organization (UNWTO), Mexico is one of the main tourist destinations in the world despite the decline from sixth to seventh place in the world ranking of countries that are visited by international tourists.

\begin{tabular}{|l|l|l|l|}
\hline \multicolumn{4}{|c|}{ International tourist arrivals 2018} \\
\hline Country & $\mathbf{2 0 1 7}$ & $\mathbf{2 0 1 8}$ & $\begin{array}{l}\text { Millions of arrivals } \\
\mathbf{2 0 1 8}\end{array}$ \\
\hline France & 1 & 1 & 91.8 \\
\hline Spain & 2 & 2 & 82.8 \\
\hline Mexico & $\mathbf{6}$ & $\mathbf{7}$ & $\mathbf{4 1 . 4}$ \\
\hline Thailand & 10 & 9 & 38.3 \\
\hline $\begin{array}{l}\text { United } \\
\text { Kingdom }\end{array}$ & 7 & 10 & 36.3 \\
\hline
\end{tabular}

Table 1 Ranking tourist activity

Source: own elaboration with data from the World Tourism Organization (UNWTO)
In addition, the cultural and gastronomic natural riches it offers, become competitive advantages that are attractive to attract visitors, so in the National Development Plan (PND, 2019-2024) one of the objectives is to position Mexico as part of the main tourist destinations through the sustainable use of national tourism heritage and natural resources. The state of Puebla occupies the sixth place in activities to provide lodging services.

\begin{tabular}{|c|l|c|}
\hline \multicolumn{3}{|c|}{ Total tourist arrivals to lodging establishments } \\
\hline Position & \multicolumn{1}{c|}{ Turistic center } & $\begin{array}{c}\text { January-April } \\
\mathbf{2 0 1 9}\end{array}$ \\
\hline 1 & Mexico City & $3^{\prime} 418,250$ \\
\hline 2 & Cancun & $2^{\prime} 943,012$ \\
\hline 6 & Puebla & $\mathbf{1}^{\prime} \mathbf{0 0 3 , 3 6 6}$ \\
\hline 9 & Monterrey & 772,617 \\
\hline 10 & $\begin{array}{l}\text { Veracruz-Boca del } \\
\text { Río }\end{array}$ & 604,675 \\
\hline
\end{tabular}

Table 2 Total tourist arrivals to lodging establishments Source own elaboration with data from the National Tourist Business Council and Datatur of the Tourism Secretariat of the Federal Government

Xicotepec de Juárez, is a Municipality located in the Sierra Norte of the State of Puebla, hosted by the Sierra Madre Oriental, enjoys a mild climate. It rains during most of the year, with annual rainfall of $2,800 \mathrm{~mm}$. It has an area of 312.30 square kilometers that place it in place 34 with respect to the other municipalities of the state. According to INEGI data until 2015, its population was composed of a total of 81,455 inhabitants, 38,757 women and 42,698 are men. With a total of 3,631 people who speak indigenous language (Náhualt, Totonaca and Otomí).

The distribution of the population by condition of economic activity is as follows: The Economically Active Population is 28,505 of which 27,324 is employed and 1,181 unemployed and 26,761 is made up of the noneconomically active population (Students, Retired, home or with some limitation physical). It is a priority for the Municipality of Xicotepec de Juárez, Puebla; properly use the natural, cultural and gastronomic resources that it possesses, in order to attract tourists to this region and take advantage of the preference that travelers have for the state of Puebla and thus strengthen their economy, contribute to the preservation of cultural roots and strengthen sustainability tour. 
It also has the recognition of the Magic Town as it has symbols, legends and history being the scene of transcendental events for our country, during the pre-Hispanic and contemporary times, it also contributes to strengthening the national identity.

Currently tourism has positioned itself as one of the most prominent economic activities worldwide; Therefore, it is necessary to create tourist products that diversify the offer of attractions in the destinations and, thus, meet the needs of tourists. Ramírez Hernández (2019), since it has a diversity of attractions, the creation of sustainable tourism is evident and in order to achieve sustainable tourism it is also essential to have a sustainable education and consider reciprocity in the relations of education in the tourism. Maludin Medina (2018).

So the University is the catalyst that allows establishing the achievement of education with sustainability. According to Montalvo \& Castillo (2018), it is necessary to facilitate the search for balances between social and environmental economic development in the localities and take advantage of their particularities through their characterization by identifying their degree of fragility, ordering them by areas of exploitation and conservation for the benefit of the local inhabitants, conserving the endemic natural resources and by specificities in a sustainable way creating selfsustainable tourism products that generate benefits to the local population.

\section{Methodology}

For this purpose, a quantitative empirical study was carried out by means of a field research instrument consisting of 62 items to try to understand and interpret reality, from the experience and perception of natural persons who develop activities in the Micro and Small Businesses sector. (MYPES) interviewed. To identify the following items: Operation, Use of Technology, Sustainability Actions, Production, Installed Capacity, Sales Management and Finance; which are applied in the Micro and Small companies located in Xicotepec de Juárez, Pue., and currently know in this Municipality, their cultural value to generate strategies that strengthen their economy contribute to the preservation of cultural roots and strengthen tourism sustainability.

\section{Results}

To determine the population, only those economic units that carry out activities in the following sectors were taken into consideration: Cultural and sports recreation services, and other recreational services were considered 44 Micro and Small Businesses (Mypes). 608 Mypes were chosen from the temporary accommodation and food and beverage preparation services sector. Adding a total of 652 companies representing the total population.

\begin{tabular}{|c|c|}
\hline Exercise & $\begin{array}{l}(21197) \\
\text { Xicotepec }\end{array}$ \\
\hline $\begin{array}{l}\text { (11) Agriculture, animal husbandry and } \\
\text { exploitation, logging, fishing and } \\
\text { hunting }\end{array}$ & 4 \\
\hline (21) Mining & 5 \\
\hline $\begin{array}{l}\text { (22) Generation, transmission and } \\
\text { distribution of electrical energy, water } \\
\text { and gas supply through pipelines to the } \\
\text { final consumer. }\end{array}$ & 6 \\
\hline (23) Construction & 24 \\
\hline$(31-33)$ Manufacturing industries & 630 \\
\hline (43) Wholesale trade & 89 \\
\hline (46) Retail trade & 1808 \\
\hline $\begin{array}{l}(48-49) \text { Transportation, mail and } \\
\text { storage }\end{array}$ & 30 \\
\hline (51) Information in mass media & 21 \\
\hline (52) Financial and insurance services & 33 \\
\hline $\begin{array}{l}\text { (53) Real estate and rental services of } \\
\text { movable and intangible assets }\end{array}$ & 37 \\
\hline $\begin{array}{l}\text { (54) Professional, scientific and } \\
\text { technical services }\end{array}$ & 69 \\
\hline (55) Corporate & 0 \\
\hline $\begin{array}{l}\text { (56) Business support services and } \\
\text { waste management and remediation } \\
\text { services }\end{array}$ & 101 \\
\hline $\begin{array}{l}\text { (71) Cultural and sports recreation } \\
\text { services, and other recreational services }\end{array}$ & 44 \\
\hline $\begin{array}{l}\text { (72) Temporary accommodation and } \\
\text { food and beverage preparation services }\end{array}$ & 608 \\
\hline TOTAL & 3509 \\
\hline
\end{tabular}

Table 3 Population choice

Source: own elaboration with INEGI data

Subsequently, the sample size was determined with a margin of error of $5 \%$ based on the population size of 652 Micro and Small companies in Xicotepec, with a $95 \%$ confidence level

$$
\begin{aligned}
& N^{*}\left(a_{c} * 0.5\right)^{2} \\
& 1+\left(e^{2 *}(N-1)\right)
\end{aligned}
$$


In the field research, a total of 242 research instruments were applied to the aforementioned sectors.

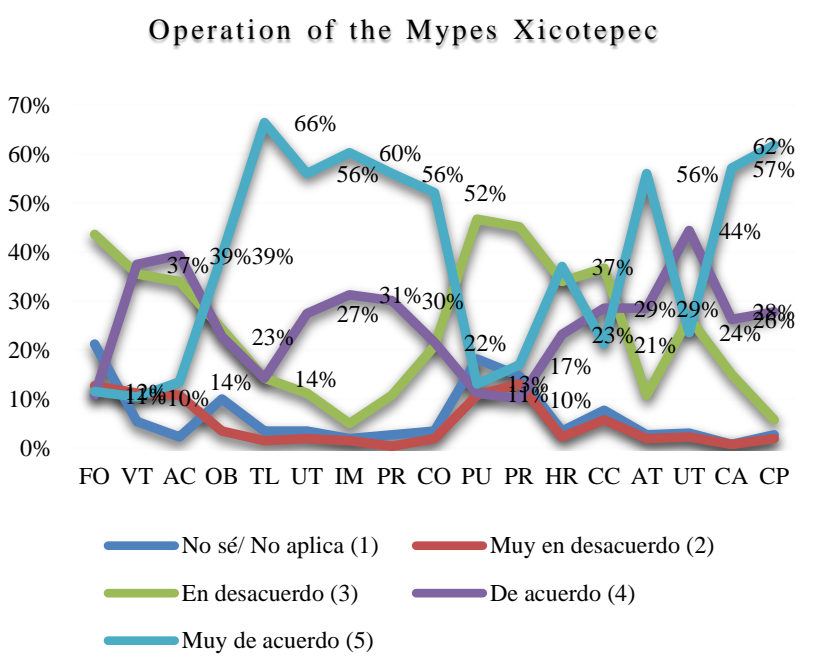

Graphic 1 Operation of the Mypes Xicotepec Source Own Elaboration

Regarding the operation of the business, $66 \%$ of microentrepreneurs know the legal procedures to operate, $56 \%$ have knowledge to calculate the profit margin, have a corporate image in their businesses and affirm that the products are similar to those of In the same way, $56 \%$ do not know their SWOT, 58\% do not advertise their business, $58 \%$ do not promote and $36 \%$ do not publish their customer service hours, $42 \%$ do not have control and registration of its customers, $57 \%$ are also interested in training, $62 \%$ compare the products of their suppliers.

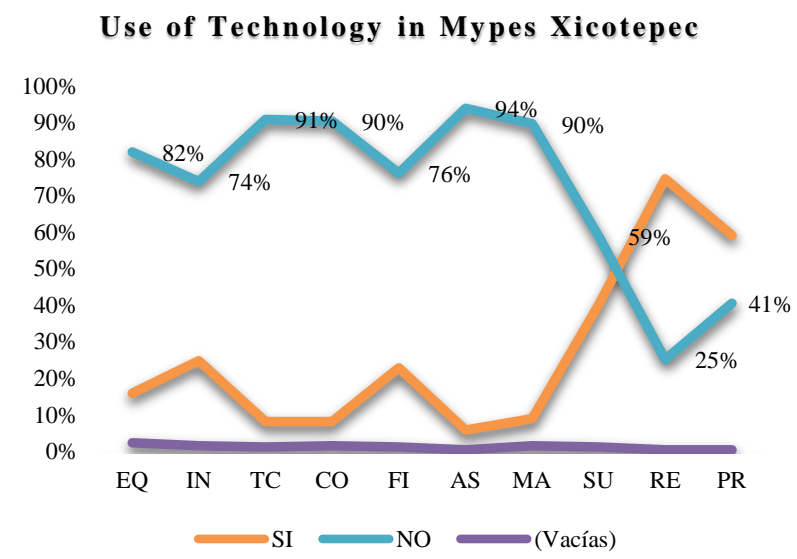

Graphic 2 Use of Mypes Technology Xicotepec Source Own Elaboration
It is perceived that $82 \%$ do not use computer equipment, $74 \%$ do not have internet in their business, $91 \%$ do not use terminals for credit card collection, $90 \%$ do not have an automated switch or answering machine, $76 \%$ do not have a signature electronic, $90 \%$ do not have operating manuals, but $75 \%$ have customer records, 59\% have policies and procedures.

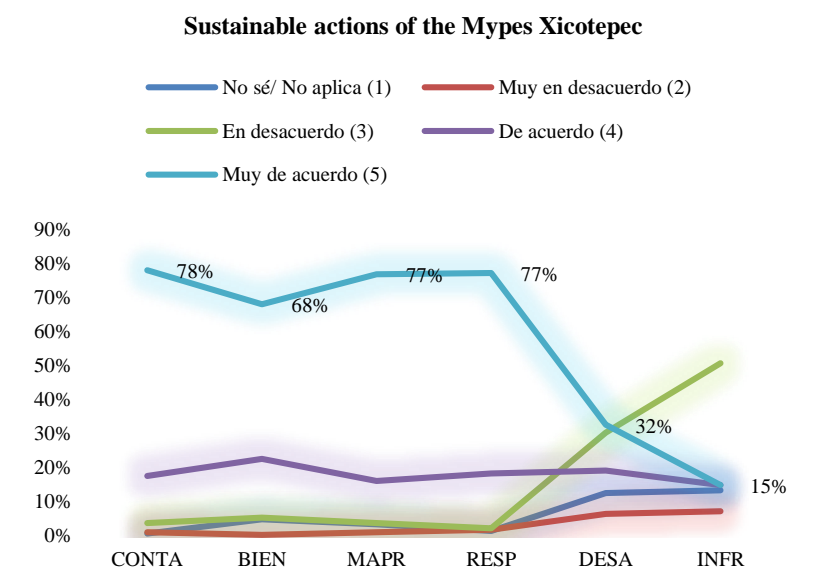

Graphic 3 Sustainable actions in the Mypes Xicotepec Source Own Elaboration

Regarding sustainability and pollution prevention, it was determined that $78 \%$ prevent pollution, $68 \%$ promote actions that generate well-being for their staff, $77 \%$ avoid bad practices such as bribes and corruption, 77\% their behavior is ethical with Your clients.

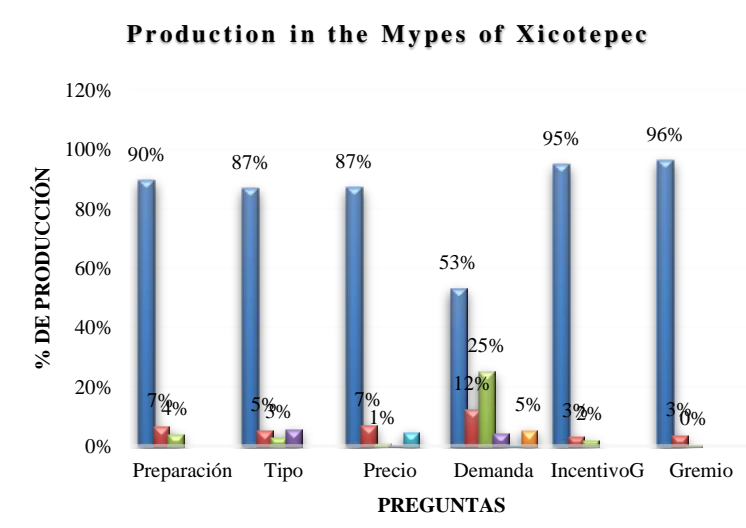

Graphic 4 Production in the Mypes Xicotepec Source Own Elaboration

The Production of Mypes in Xicotepec is focused on producing food by hand in $90 \%$ of its businesses, $7 \%$ use technology devices and traditional regional food is best selling with $87 \%$, prices are very accessible. 
From $\$ 50$ pesos to $\$ 200,87 \%$ of businesses offer a menu of 50 to 100 pesos, $7 \%$ of businesses have a menu of $\$ 100$ to $\$ 150$ pesos and $1 \%$ has a menu of 150 to 200 pesos, demand of the Mexican dishes is the highest percentage with $53 \%$, fast food with $25 \%$ and $12 \%$ are occupied by restaurants with a la carte food, only $4 \%$ make international food; more than $95 \%$ do not receive any incentive and do not belong to any business association.

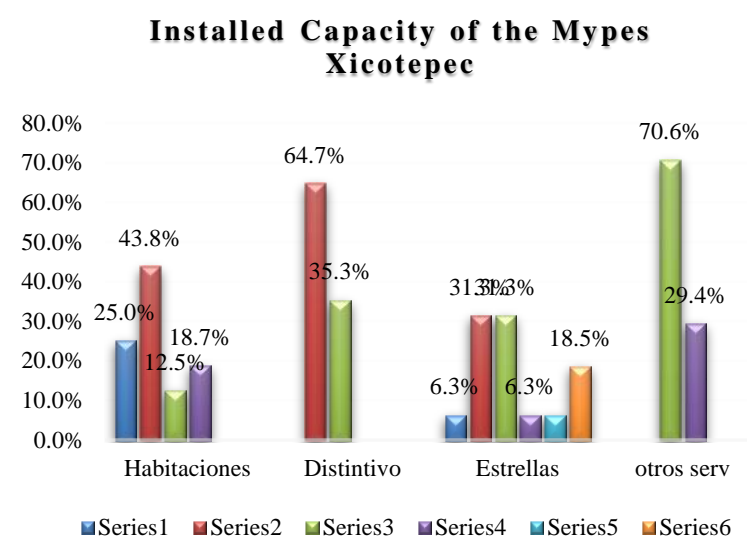

Graphic 5 Capacity installed in the Mypes Xicotepec Source Own Elaboration

Hotels that have between 5 and 10 rooms are $25 \%$, most hotels have between 10 and 20 rooms with $43.8 \%$, the rest $12.5 \%$ and $18.7 \%$ are for hotels with more than 30 rooms. It should be noted that $64.7 \%$ of the hotels have badges (corporate image) and 35.3 do not have them, as for the stars $6.3 \%$ have the 5 stars, 31.3 are 4 -star hotels and 31.3 are 3 stars, and $6.3 \%$ are occupied by hotels 2 and 1 star, and $18.8 \%$ responded that they do not apply that degree of evaluation to their facilities.

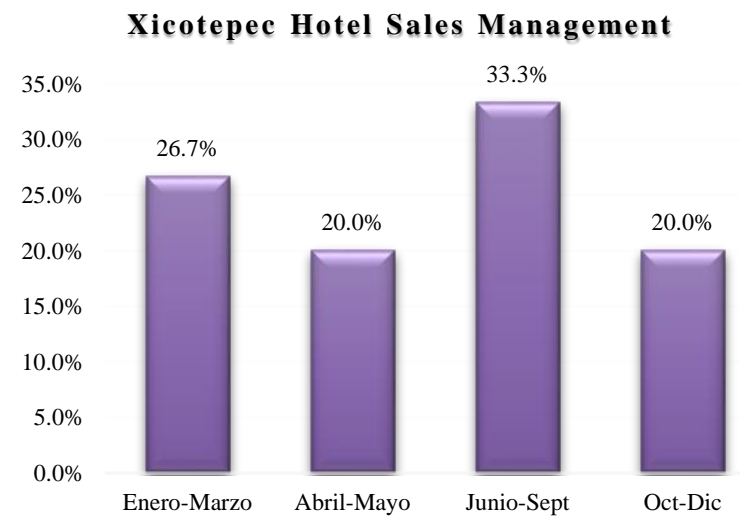

Graphic 6 Xicotepec Hotel Sales Management Source Own Elaboration
The hotels declare that the period in which they receive lower income is $33.3 \%$ in June-September, with the same trend JanuaryMarch with $26.7 \%$ and the remaining 3 quarters remain with $20 \%$, identifying the best periods for services Lodging are: April-May and October December.

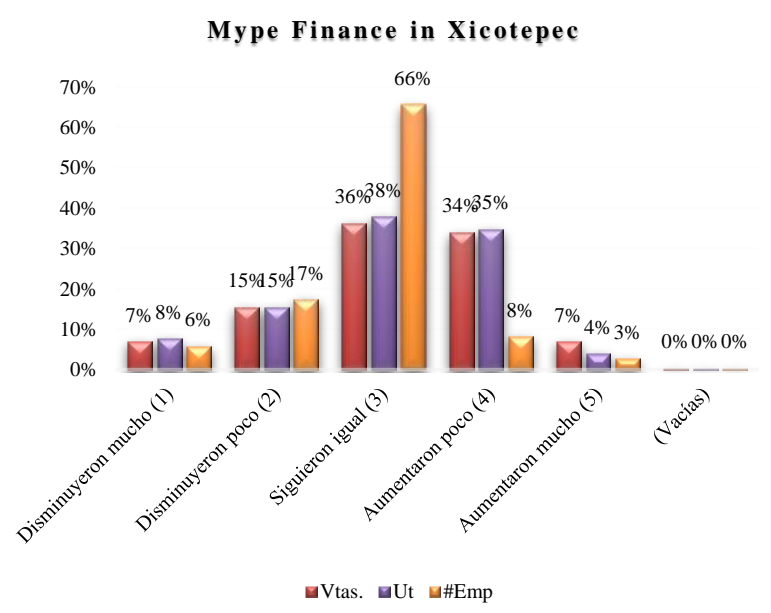

Graphic 7 Finance of the MSe's in Xicotepec Source Own Elaboration

It can be seen that the bars with the highest percentage are focused on indicating that Mypes finances continued without change in the last 3 years, $36 \%$ affirm that their sales remain the same, $38 \%$ state that their profits remain the same, and $66 \%$ recognizes that the number of employees has increased. In terms of growth these increased little in sales with $34 \%$, those that increased their profits with $35 \%$ and those that increased little personal only $8 \%$.

\section{Results}

Xicotepec de Juárez is one of the 217 municipalities that make up the State of Puebla recognized by the Ministry of Tourism of Mexico as a magical town, because of its geographical location it is an intermediate point between Mexico City and the port of Veracruz is a strategic place to offer tourist and gastronomic services, however, the favorable initial condition has decreased for Xicotepec de Juárez, due to the culmination of the Mexico-Tuxpan highway, as this causes not all tourists traveling to both destinations in the mentioned cities to stop in Xicotepec de Juárez, situation that gives rise to the present research focused on diagnosing the business assets of companies in terms of business and tourism culture to present strategies that contribute to the business development of the Mypes of Xicotepec de Juárez. 
It is to be recognized that, like the Mypes of the majority of Municipalities that make up the country, in Xicotepec they suffer from the same problems as: administrative problems, lack of liquidity, absence of advertising strategies, lack of organization manuals, policies and procedures; also sales levels mostly without growth and lack of technology either to communicate their products and services or as tools to control their finances; For this reason, when analyzing the statistical data, the following strategies were formulated, which could later become the object of study to identify the impact that they could have on the benefit of economic development in the aforementioned Municipality. For this purpose the following is suggested:

Establish training projects in a simplified way because entrepreneurs do not have much time for theory, teaching business control methods and procedures applied to the daily practice of the activities they perform.

Promote the culture of management and use of information technologies both for the control of its customers and to broaden its growth horizon.

Make agreements with the Municipal and Higher Education authorities and also with the business associations so that in a tripartite way there will be intervention of the universities, creating and adapting better business models, by the areas of university research and teaching, supported by the periods in which that the students give back to society what they have learned through the social service and stay, in coordination with the support of the Municipality to grant facilities in the training processes for the benefit of the Mypes, all articulated with the business associations.

Rescue the base of the gastronomic menu as heritage of the region to strengthen the local identity itself, consequently its culture and customs that laid the foundations to acquire the denomination of magical town, to adequately promote its cultural wealth to visitors who integrate national tourism and international visiting the region.

To increase sales in the Mypes, training on the use of social networks and advertising media of lower cost should be provided, derived from the low budget with which this sector operates.

\section{Acknowledgments}

We appreciate the unconditional support granted by the highest authorities of our M.B.A. Gerardo Vargas Ortíz, Rector; to Mtra. Altagracia Carrillo Parra, Academic Secretary and M.I. Juan Carlos Carmona González, Manager of the Administrative Economic Division of the Technological University of Xicotepec de Juárez to achieve the presentation of this research work.

\section{Conclusions}

The project supplies from the tourism angle associated with gastronomy since these sectors are strengthened as a magical town, generating a large part of the economy, which sustains the region to identify, however many of which have been missing, culture as their way of production and preparation of food for this reason when carrying out this project is to determine the sectors that most benefit the magical people to implement strategies that help to improve.

\section{References}

Directorio Estadístico Nacional de Unidades Económicas, INEGI. Disponible en: https://www.inegi.org.mx/app/mapa/denue/ consultado el 15 de Septiembre de 2019.

Galimberti, C. (2013). Paisaje del agua. Una mirada hacia el frente costero del Área Metropolitana de Ro- sario, Revista Iberoamericana de Urbanismo, RUBB, N o9. En http://www.riurb.com/n9/09_05_Galim-

berti.pdf consultado el 15 de Septiembre de 2019.

Organización Mundial de Turismo (Panorama OMT de Turismo Internacional, mayo 2019) Disponible en: https://www.datatur.sectur.gob.mx/SitePages/R ankingOMT.aspx Consultado el 15 de Septiembre de 2019.

Panorama de la actividad turística en México. Disponible en: https://www.cnet.org.mx/docs/Panorama27.pdf consultado el 10 de Septiembre de 2019.

Plan Nacional de Desarrollo 2019-2024. Gobierno de México. Diario Oficial de la Federación Disponible en: https://www.dof.gob.mx/nota_detalle.php?codi go $=5565599 \&$ fecha $=12 / 07 / 2019$ Consultado el 11 de Septiembre de 2019.

VELÁZQUEZ-VARGAS, José Rubén, CRUZ-CABRERA, Clotilde, CARMONA-GONZÁLEZ, Juan Carlos and VAZQUEZ-ARROYO, Felipe. Strategies to boost economic and tourist development, under the scheme of Magical Towns in Xicotepec de Juárez, Puebla. ECORFAN Journal-Republic of Cameroon. 2019 
Medina Maludin (2018). El Turismo Sustentable Entrelazado al Desarrollo Endógeno para el Impulso del Potencial Histórico-social-cultural Local, una Construcción Teorética Educativa en el Contexto Universitario. Centro de Estudios e Investigación Área Ciencias de la Educación (Ceiacerg)

http://centrodeinvestigacion.eshost.com.ar/imag es/pdf/1 ra-edicion-finalmente-la-revistacientifica-culminada.pdf?i=1 Consultado el 14 de Septiembre de 2019.

Montalvo Vargas, Ramos; Castillo Ramiro, Juan Javier. (2018) Estimación de la Capacidad de Carga Turística en Agua Selva (Tabasco México) Base para la planificación y el desarrollo regional. Estudios y Perspectivas en Turismo, vol. 27, núm. 2, 2018, Febrero-Abril, pp. 295-315 https://www.estudiosenturismo.com.ar/PDF/V2 7/N02/v27n2.pdf Consultado el 15 de Septiembre de 2019.

Nieto, A. (2013). Participación Comunitaria en inicia- tivas de ecoturismo en la Vereda Los Soches, loca- lidad de Usme, Bogotá, Revista Interamericana de Ambiente y Turismo. vol. 9, $\mathrm{N}^{\circ} \quad 2 . \quad$ En:http://riat.utalca.cl/index.php/test/article/view/254 Consultado el 14 de Septiembre de 2019.

Ramírez Hernández, O.I. (2019). Propuesta metodológica para la generación de productos turísticos a partir de la comunidad local. Retos Revista de Ciencias de la Administración y Economía, 9(17), 127-143. https://doi.org/10.17163/ret.n17.2019.08 Consultado el 15 de Septiembre de 2019.

Sistema Nacional de Información Municipal (SNIM), Instituto Nacional para el Federalismo y el Desarrollo Municipal (INAFED) Secretaría de Gobernación. http://www.snim.rami.gob.mx Consultado el 15 de Septiembre de 2019. 